\title{
Decolonizing Race and Gender Intersectionality in Education: A Collaborative Critical Autoethnography of Hope, Healing and Justice
}

\author{
Lyric Harris ${ }^{1}$, Marcia J. Watson-Vandiver ${ }^{1 *}$
}

${ }^{1}$ Towson University, USA

\section{*Corresponding Author: mjwatson@towson.edu}

Citation: Harris, L. and Watson-Vandiver, M. J. (2020). Decolonizing Race and Gender Intersectionality in Education: A Collaborative Critical Autoethnography of Hope, Healing and Justice, Journal of Cultural Analysis and Social Change, 5(2), 09. https://doi.org/10.20897/jcasc/9321

Published: December 18, 2020

\begin{abstract}
This article provides a collaborative critical autoethnography of the educational experiences of two women of African descent, from the perspectives of an undergraduate student and university professor. Using decolonial intersectionality as the theoretical framework, the authors interpret their schooling experiences through a decolonial epistemological lens and identify ways in which education serves as both a divider and equalizer for students. Whereas existing research suggests that transformative education is made possible through expanded and engaged pedagogy, our autoethnographic narratives submit that curricula are central to this discussion as well. Results of this study posit that critical education can provide opportunities for gleaning into diverse perspectives and oppositional histories. Additionally, when implemented with a critical lens, educational disciplines such as history and social science can provide hope, healing, and justice.
\end{abstract}

Keywords: autoethnography, Black education, decoloniality, qualitative research, intersectionality

Authors' Note: Due to the U.S. contextualization of this article, the terms "African American" and "Black" are used interchangeably. We acknowledge the potential ethnic inconsistencies between (and within) these two terms. Additionally, because of our own ethnic distinctions, we use the term Women of African Descent to describe our collective experience. The term "African descent" describes historical and diasporic relations to Africa via race and ethnicity, not necessarily native birth or citizenship.

\section{INTRODUCTION}

The notion that we are living through 'post-racial' times is asinine (Coates, 2015). The recent racially motivated deaths of Walter Wallace, Jr. [Philadelphia, Pennsylvania], George Floyd [Minneapolis, Minnesota], Breonna Taylor [Louisville, Kentucky], Ahmaud Arbery [Brunswick, Georgia], and Tony McDade [Tallahassee, Florida] prove that even in 2020, the complicated milieu of American racism calls for our attention (Costello \& Duvall, 2020; Deliso, 2020; McLaughlin, 2020; Murphy, 2020). Whereas schools would seem like optimal spaces for critical inquiry, most classrooms have been standardized to circumvent critical race discussions (Dei, 2003, 2012; Flaherty, 2014; George \& Puente, 2015; Moulthorp, 2015). Education settings rooted in critical discourse can provide insight into the ways in which the U.S. is structured by race and racism. The recent shooting deaths of unarmed Black citizens by police have made this even more apparent in the $21^{\text {st }}$ century. Yet, the capacity to examine these structures is denied by education policies and directives. Thus, the transformative power of education is restricted when conversations about real issues in society are avoided (Baker, 2020; Dei, 2003, 2012; Thurber, Harbin, \& Brandy, 2020). This article honors the countless lives that have been impacted by racial injustice, bigotry, discrimination, and 
xenophobia and interrogates ways that curricula can further explore the topic of race and gender. Using an autoethnography as mode of inquiry, this article uplifts shared narratives of two Women of African Descent ${ }^{1}$ to explore the critical role of education for facilitating meaningful conversations about racial understandings and identity.

In our exploration, we rely on collaborative critical autoethnography to examine the collective experiences of professor and student with similar intersectional identities as Women of African Descent in a Predominately-White university [PWI ${ }^{2}$ setting. According to Moore at al. (2013), collaborative autoethnographies that include both faculty and students are transformative mechanisms used to more broadly understand experience and identity. To that end, we agree with Anderson's (2015) definition of collaborative ethnographies that uses a dual analysis to sensitize the individual nature of participant experiences and needs. Anderson (2015) notes, "building research around the crafting of stories about personal experiences provides an insider's view that enriches our outsider perspectives when probing the experiences of others and interpreting results from studies using other methods" (para. 3). Thus, the remainder of the article will explore the following: a) theoretical framework of decolonial intersectionality, b) collaborative critical autoethnography, c) preliminary decolonial understandings, d) selfactualizations of colonialism and decoloniality, e) colonialism's role in race and gender divides, f) decolonial education as a force of activism, and g) a discussion on critical thinking and education's role as an equalizer for change.

\section{THEORETICAL FRAMEWORK: DECOLONIAL INTERSECTIONALITY}

This work is framed by the framework of decolonial intersectionality. Many contend that concepts of "intersectionality" must begin with the Combahee River Statement of $1977^{3}$ and later Crenshaw's (1991) analysis of structural and political dimensions of intersectional oppression. Crenshaw's ground-breaking claims problematized monolithic assertions of race and gender and instead surfaced the "simultaneity" within modes of difference (Ferguson, 2012). Whereas Crenshaw's research focused on Black women's experiences within the legal field, more contemporary studies on intersectionality provide an expanded milieu for research inquiry. Lorde (1984/2007) and Collins (2000) also note the compounding complexities of navigating White patriarchy as Black women. In addition to race and gender specifically, Collins (2000) coins the term "matrix of domination" to describe additional layers of oppression such as class, sexuality, age and ability. Likewise, Grzanka (2014) comprehensively disentangles topics of intersectionality within the topics of law, epistemology, identity, culture and representation, space and community, resistance and activism, migration, politics and justice, science, and research methods. Grzanka's research anthology builds upon Crenshaw's assertions and provides a number of notable studies that examine intersectionality in the $21^{\text {st }}$ century.

Despite these efforts, Salem (2014) asserts that dominant narratives on gender and race persist, "thus allowing certain ideas and moments to gain currency" (p. 3). This is seen in education, as select White narratives are propagated in the curriculum, while marginalizing non-White perspectives. Thus, decolonial intersectionality more narrowly seeks "compelling, complex analyses" of how insidious issues like colonialism, sexism, nationalism, and neoliberal capitalism, "either singularly or in combination" inform realities (Collins, 2019, p. 5). This often requires the dismissal of arbitrary binaries for group experiences. It is important to note that we purposefully considered this when selecting our identity terminology for this article. Using the term Women of African Descent, versus the proverbial term "African American," was intentional and mirrored the very concept of decolonial intersectionality.

Shohat and Stam (1994) suggest the need for resistance through polycentrism while debunking the arbitrariness of standard categories of identity that are "categorically hybrid" (p. 13). By decentering Western terminologies for race and gender, we put forward this article as a form of academic resistance both in diction and methodological approach. Similar to Crenshaw's (1991) research on Black women's experiences, this research examines concepts of layered discrimination in relation to decolonial awareness and framing. However, while Crenshaw focused on political and legal experiences, this research examines lived educational experiences. Additionally, Collins' (2019) research on intersectionality suggests that we must critically reflect on assumptions, epistemologies, and methods.

\footnotetext{
${ }^{1}$ Because of our own ethnic distinctions, we use the term Women of African Descent to describe our collective experience. The term "African descent" describes historical and diasporic relations to Africa via race and ethnicity, not necessarily native birth or citizenship.

${ }^{2}$ We distinguish the term PWI [Predominately-White Instructions] to describe university settings where students of color represent the minority population. In U.S. contexts, there are distinctions between predominately White institutions and Historically Black Colleges and Universities [HBCUs]. Since this paper investigates concepts of race in a university setting, the racial context of a PWI is much different from HBCUs where Black students would represent the majority.

${ }^{3}$ The Combahee River Statement is an essay written by Black feminists formed out of Boston, Massachusetts. This group criticized other activist movements, such as White feminism and the Civil Rights Movement in failing to adequately address the needs of Black women and Black Queer women. Today, it is regarded as one of the foremost collections of intersectional thought.
} 
As such, this article focuses on a newly-expanded autoethnographic methodological framing to disentangle the lived education experiences of $W$ omen of African Descent in the U.S.

\section{COLLABORATIVE CRITICAL AUTOETHNOGRAPHY}

Autoethnography is a qualitative method of inquiry that relies on self-introspection and first-person representation within the ethnographic experience (Adams, Jones, \& Ellis, 2014; Chang, 2008). The purpose of autoethnography is to translate lived experiences for outside readers to understand. This relies on a myriad of interconnected research methods, such as narrative inquiry, ethnography, and phenomenology (Marx, Pennington, \& Chang, 2017). However, the increased popularity of autoethnographic research stems from the understanding that self is an appropriate space for exploration and investigation. In this way, autoethnographies serve as a repositioning tool for narrative inquiry that also allows the author to be involved in, not separate from, their cultural experiences. It is important to mention that autoethnographies are not without critique. For example, autoethnography's "boundaries, foundations, formatting, and purpose can seem nebulous and untrustworthy," especially since this is a newly evolving research method (Marx, Pennington, \& Chang, 2017, p. 3). In that same vein, critical autoethnographies are not widely studied. Rather intuitively, critical autoethnographies imbue autoethnographic research methods with a critical lens (Boylorn \& Orbe, 2014; Marx, Pennington, \& Chang, 2017). They allows the author to explore personal accounts of lived experiences involving identity and culture. They also allows the author to explore experiences of marginalization, power, and privilege (Boylorn \& Orbe, 2014).

Collaborative critical autoethnographies provide collective agency within the autoethnographic experience (Chang, Ngunjiri, \& Hernandez, 2013). The term critical collaborative ethnography refers to, “ $\ldots$ a practice of ethnography that is invested in questioning the boundaries of power relations between the researcher and the researched for the specific purpose of bringing about social change" (Bhattacharya, 2008, p. 306). In this sense, collaborative autoethnographies provide "a form of narrative inquiry further legitimatizing the personal stories and experiences we shared" (Gleiman et al., 2015, p. 3). As such, professor and student autoethnographies facilitate a "process of writing and reflection" (Moore et al., 2013, p. 2). According to Wolfe, Nelson, and Seamster (2018), the data collection process in collaborative autoethnographies involves individual introspective reflections that highlight poignant and memorable learning experiences. These individual reflections can be arranged by age group, learning level, or using any categorical or topical theme determined by the researcher(s). Data to be included in autoethnographic are narrative in nature, such as remembered experiences, poignant memories, feelings or sensory information, or general retrospective thoughts. For the sake of this study, our autoethnographic snapshots provide memorable vignettes, organized by conceptual topic. Both members of the research team provided autoethnographic accounts ranging from elementary school through postsecondary education. After the autoethnographic narratives were collected, the researchers met to share and make initial meaning of the narratives at hand.

Using collaborative critical autoethnography as the mode of inquiry, this paper explores the following question: From your experience, in what ways has education served as a divider and/or equalizer in terms of race, gender, and/or class? Throughout our interrogation of colonialism and education, we provide autoethnographic narratives of racial and identity awareness. We use narrative snapshots to describe experiential evidences of curricular inequity and education's role in social control (Freire, 1970/2000, 1973; Giroux, 1997). As suggested, these narratives work in tandem and serve as a collaborative critical autoethnography that provides a collective snapshot of professor and student experience. (For the sake of consistency, we have bracketed our names throughout the article as [Undergraduate Student] and [University Professor]).

\section{Participants: Undergraduate Student and University Professor}

We are both affiliated with the same university and share similar experiences in relation to navigating a Predominately-White Institution [PWI] as Women of African Descent. Our respective identities are important to highlight: [the undergraduate student] is a Moorish Muslim woman, whereas [the university professor] describes identifies as Black, ${ }^{4}$ or African American. The term Women of African Descent is the decided term that encapsulates both of our identities. Through office hours and frequent conversation, we realized we shared a common understanding of pre-colonial African history and its relation to our own educational understandings. Pre-colonial, in this sense, refers to history before transatlantic slavery. To that end, we collectively understand how "Blackness" and the history of the African Diaspora have been misconstrued in schools. Thus, one of the many common bonds

\footnotetext{
${ }^{4}$ We agree with the American Psychological Association's (APA) assertion that racial and ethnic groups are designated by proper nouns and should be capitalized. Therefore, this manuscript uses "Black" and "White" instead of "black" and "white" to describe racial groups.
} 
shared between us resides in the understanding that corrective bistory has helped in our own self-liberation processes. We collectively acknowledge that most of history frameworks in K-16 $6^{5}$ education glorify European history, while marginalizing non-White perspectives. We also understand the undeniable historical underpinnings that have contributed to systemic injustice. To that end, in our current space, we have navigated the academy with an "awareness" that can be both liberating and oppressive.

\section{PRELIMINARY PRE-COLONIAL UNDERSTANDINGS}

[Undergraduate Student]: Colonialism, war between the native people and European settlers, slavery, religion, and that Christopher Columbus was not the first to discover America, like textbooks would claim, was taught to me at an early age. This fostered my interest to learn more and to question what I have learned.

[University Professor]: It was not until my graduate studies where I fully understood the importance of pre-colonial Black History. I participated in Black. History programs as a cbild and taking Africana Studies classes in undergrad, but my self-indulgence for Black issues and "wokeness" did not come until graduate school.

Critical perspectives maintain that the role of education in the United States has been a tool of empire and colonialism (Wiggan, Scott, Watson, \& Reynolds, 2014). Considering that the United States was a settler colony, religious resistance and academic freedom often worked in tandem as tools for synchronous liberation and oppression (ibid.). Further, knowledge in the United States has always been skewed to align with White, AngloSaxon, Protestant values. Women, racial minorities, and the poor have historically been underserved in education. As such, cultural knowledge is often considered a "specialized" topic that is inaccessible and unavailable in mainstream schools (Loewen, 1995). Since both researchers had access to cultural curricula during their formative years, this autoethnography allows for more nuanced explorations of our retrospective educational experiences.

African history has been largely misconstrued by mainstream Western thought (Asante, 1990; Diop, 1987). While recognizing education's role in social control (Freire, 1970/2000, 1973; Giroux, 1997), we acknowledge that history, specifically, has been disrupted for people of color. As such, we agree with Giroux's (1997) assertions that historical illiteracy is both an engrained and intentional phenomenon that is a by-product of knowledge control. As such, we both attest to engagement with pre-colonial history being transformative in our own self-actualization experiences. Here, we align self-actualization with hooks' (1994) concept of "engaged pedagogy," which encourages students to connect the "will to know with the will to become" (p. 19). hooks suggests that the role of instruction is to incorporate narratives and personal experiences of both the teacher and students to decenter instructors as experts, or silent interrogators. Instead, according to hooks (1994), education must embrace the challenge of self-actualization, which in turn is central to making their teaching a site of resistance. Thus, it is important to highlight certain historical moments that are most crucial to our understandings of identity. Much of this historical information is not taught in schools and was only acquired through intensive critical engagements with historical texts and primary documents. For [the undergraduate student], it came through historically conscious parents who instilled corrective history at a young age. For [the university professor], it came through graduate school and independent research with a decolonial historian and scholar. There are a couple of historical moments to highlight, which resonate with our personal understandings of the world.

To start, we acknowledge that the history of North America omits significant portions of indigenous histories and African influences. In the $15^{\text {th }}$ and $16^{\text {th }}$ centuries, Ancient Egyptian artifacts were found in the Americas (Wiener, 1922; Van Sertima, 1976/2003). Additionally, Wiercinski (1972) discovered African skulls at Olmec sites in Tlatilco, Cerro de las Mesas, and Monte Alban (Borders, 2010). In an analysis of these skulls, Borders (2010) and Wiercinski 91972) contend that pre-colonial African presence had been evident throughout the world. In relation to North America specifically, Van Sertima's (1976/2003) They Came Before Columbus also confirms these findings. Van Sertima confirms that Spain observed African presence in the "New World" when Vasco Balboa stood on the summit of Quarequa (1976/2003). In 1513, Balboa and his companions continued south of the Southern Sea and stumbled upon an encounter between Indians and African captives. The Spaniards shortly discovered that the Africans had a settlement nearby and the native people and Africans were at war. Moreover, Peter Martyr d'Anghiera [ca. 1504-1526] reported this incident to the Spanish and described "finding negroes" in this province, and "they were fierce" (1912).

Another evidence of African world presence in the Americas was a detailed encounter in Columbia, in an island off Cartagena. Fray Gregoria Garcia, a Dominican priest, documented the account and notes, "here were found slaves, of the lord-Negroes-who were the first our people saw in the Indies" (Sertima, 2003, p. 24). Many of these findings can also be confirmed in primary sources. For example, Greek historian Herodutus (440 B.C.E./2014) confirms these findings in the book Histories, when he mentions the exquisite maritime skills of ancient Egyptians under the leadership of Sesostris [Egyptian]:

${ }^{5} \mathrm{~K}-16$ describes kindergarten through postsecondary education [typically ages 5-22 years old].

$4 / 16$

(C) 2020 by Author/s 
[Sesostris] first of all set out with ships of war from the Arabian gulf and subdued those who dwelt by the shores of the Erythraian Sea, until as he sailed he came to a sea which could not further be navigated by reason of shoals: then secondly, after he had returned to Egypt... He [Sesostris] traversed the continent, until at last he passed over to Europe from Asia and subdued the Scythians and also the Thracians. These, I am of the opinion, were the furthest people to which the Egyptian army came. (p. 103)

Herodotus wrote of King Ramses III moving alongside a group of Africans at sea claiming the Africans had astonishing navigational skills (Chengu, 2014). Additionally, historians have discovered evidence that suggests Africans were master shipbuilders and posed maritime expertise, prior to European colonization (Barton, 2001; Law, 1989; Whitewright, 2018). Aside from their geographical savvy, additional praise of pre-colonial Africans is found in several primary sources from Greek philosophers, including: Herodotus' Histories (440 B.C.E./2014), Aristotle's Metaphysics (350 B.C.E./1966), and Plutarch's Parallel Lives (75 C.E./2012). Yet, it is conspicuous that this information is not found in mainstream U.S. curricula (Dei, 2012; Loewen, 1995). Whereas widespread racial representation can be empowering, the historical role of racism in the U.S. subjugates, or more accurately - omits, non-White perspectives. As such, K-16 history is misconstrued and falsified. Whereas, Black history is often limited to slavery and the Civil Rights Movement, we found collective liberation in discovering triumphant and venerating historical stories like these.

\section{SELF-ACTUALIZATION OF COLONIALISM AND DECOLONIALITY}

[Undergraduate Student]: There was a ceremony conducted by my (second) elementary school during Black History Month, in which I played as an African dancer. That experience made me feel like I belonged and proud to be Black. Afterwards, I asked my father what African country we originated from. He never gave a direct answer but overtime told me stories of our history and what being Black meant.

[University Professor]: In elementary and middle school, there was probably no assignment more traumatic for me than "family trees." It was always a take-home project and always a big deal for the social studies or literature unit that we were studying. As an African American woman whose parents were from the Jim Crow South and whose grandparents were descendants of sharecroppers, I had no earthly idea where my ancestors came from. We had just been given the family tree assignment on Friday and it was due the following Monday. I will never forget asking my parents, "What should I put on my tree?" My parents proudly told me to put "Africa." So that's what I did.

It is important to note that due to our geographical proxy, our autoethnographic accounts focus on decolonialism in the United States, specifically. Interestingly, in both of our narratives, we highlighted memories of racial actualizations that focused on slavery. These moments yielded increased personalized awareness of U.S. slavery and its tangible impact on family dynamics and identity from a young age. As such, psychologists Kurtis and Adams (2017) note there are two strategies for decolonizing awareness. First, decolonization normalizes patterns of experience in diverse Majority-World settings that hegemonic discourses portray as abnormal or suboptimal. The second decolonizing strategy involves denaturalizing patterns of hegemonic standardization in discourse. Here, rather than portray Western understandings as the "vanguard" of liberation, this analysis instead deploys diverse perspectives to illuminate concepts of privilege that undermine its "liberatory potential" (p. 46).

Decoloniality questions and problematizes Eurocentric approaches to history. It is important to briefly note that Shohat and Stam (1994) assert that colonialism pre-existed European colonialism, since it was practiced in Greece and Rome, and by the Aztecs, Incas, and other cultural groups. This notwithstanding, the term describes decolonial thinking, knowing, and doing (Mignolo, 2011). It involves an active exploration of power structures involved with knowledge distortion (Mignolo, 2007). Mignolo and Walsh (2018) describe a matrix of power and assert the necessity to delink from the colonial matrix and Western "universals." One of the most dangerous components of Western, mainstream approaches are their universal adoption as truth (Semali \& Kincheloe, 1999). Semali and Kincheloe (1999) contend:

Modernist science produces universal histories, defines civilization, and determines reality: such capabilities legitimate particular ways of seeing and, concurrently, delegitimate others. Such an ability is imperialistic; as it operates to characterize indigenous knowledge as inadequate and inferior. (p. 29)

In U.S. contexts, the role of colonialism via land acquisition and genocide laid a structural foundation to Eurocentric capitalism. In this sense, race and capitalism served as primary conduits of social control (Williams, 1994). In that same vein, with the rise of capitalism and colonialism in North America came equal resistance. Decolonial thought derives from this resistance.

Decoloniality works in tandem with other anti-oppressive educational movements, such as gender studies and ethnic studies programs. Several grassroots movements, such as Freedom Schools in Mississippi, the Black Panther 
Party in California, and La Raza Studies in Arizona, have worked continuously to counteract Eurocentric epistemologies. In a decolonial sense, the denigration of indigenous knowledge, “...cannot be separated from the oppression of indigenous peoples" (Semali \& Kincheloe, 1999, p. 29). Thus, decolonial epistemologies acknowledge the marginalization of indigenous thought and seek to recentralize it. Decoloniality seeks to, “... make visible, open up, and advance radically distinct perspectives and positionalities that displace Western rationality as the only framework and possibility of existence, analysis, and thought" (Mignolog \& Walsh, 2018, p. 17). To accomplish this frame of thinking involves praxis: critical questioning, reflection, and reformation. In this sense, praxis is a critical pathway that leads to ongoing and intentional action. Since colonialism and capitalism are active mechanisms, so too is the ongoing resistance of decoloniality.

\section{COLONIALISM AND THE RISE OF RACE AND GENDER DIVIDES}

The role of U.S. colonialism and its impact on student development is imperative to discuss. It is important to understand the purpose of education in America and interrogate how educational systems have played a role in encouraging disparity and inequality. To that end, it is important to consider the history of societies in order to uncover historical underpinnings of discrimination and inequality. In modern contexts, O'Neil (2015) and O'Neil and Rogowski (2013) examine the history of contemporary society and highlight critical issues in relation to colonialism. European colonialism and imperialism are major drivers that created systems of privilege for White male domination, leading to inequality and the marginalization of others (Napolitano, 2009; O'Neil, 2015). This is especially true in the United States, which has been involved in both colonial and imperial expansion. Whereas colonialism is the physical occupation of a foreign territory through military force, businesses, or settlers, imperialism involves a state extending its reach beyond its borders (O'Neil, 2015). American colonialism, which is undergirded by slavery and genocide, has reshaped and defined national and ethnic identities in three distinct ways. First, the notion of race and its corresponding negative views [i.e. racism] were created to reify existing social structures (Marks, 2008; Sanders, 1969; Smedley, 1999). Second, gender and gender roles were introduced to decrease women's autonomy (Boserup, 1970). Third, the replacement of agricultural societies with industrialism reinforced capitalism and exploited the working class (O'Neil, 2015). As such, the lingering effects of social stratification impact minorities in America today. This is evidenced through several contemporary issues, including: housing disparities, gender inequity, educational access, criminal justice, etc. (Alexander, 2012; DuBois, 1899; Williamson, Rhodes, \& Dunson, 2007).

We value the transformative power of critical education and yet many students today lack a mastery of historical knowledge. We believe it is important to identify systemic and deep-rooted explanations for modern societal problems, as historical knowledge helps to contextualize contemporary social issues. To that end, the following sections provide a more in-depth look into colonialism's role in gender and racial stratification and how we navigated moments of self-actualization as Women of African Descent.

\section{Colonialism and Gender in the U.S.}

[Undergraduate Student]: Without enrolling in my Women's Perspectives and History Post-Civil War classes, I would not have support or even concluded that there was an issue or disparity between women and men in the work place and education.

[University Professor]: I was always told to work twice as hard, because I am a Black woman. Growing up, I was told that nothing in life would be given to me, to never expect handouts, and do my absolute best - because that would be the only way I could succeed in life. All of those pieces of advice were given to me as an attribution to my identity. I have always lived with those expectations. Even as a professor today, I live with the mantra: "Work twice as hard, for half the credit." I've always considered it unfair, but I have not known life to be any other way. In a way, it has prepared me for the ills of academy. You see gender disparities in a multitude of ways.

Our self-actualization of gender stems from deeply embedded beliefs about inequity. Zakaria (2007) posits the concept of "liberty" in the West derived from early Christian influences (i.e. the Roman Empire). Whereas European immigrants flocked to America to obtain religious freedom and to gain economic power, their resistance to monarchial government replaced religious piety with individualism. Thus, the push for capitalism eliminated the powers of monarchies and replaced it with a system based on individual and property rights (O’Neil, 2015). The concept of property rights and citizenship, in turn, also intersected with gender beliefs. In fact, politicians of the $16^{\text {th }}$ and $17^{\text {th }}$ centuries thought, "women's political identity should be restricted because their presence in politics was immoral, corruptive, and potentially disruptive, and the women should be represented by fathers, husbands, or brothers." (Shaw and Lee, 2012, p. 613). The separation of gender in early U.S. schools was a $17^{\text {th }}$ century impetus for gender divides in education. As a note, this concept of liberty or religious freedom was even a source of contention in the creation of the Pledge of Allegiance of the United States [1892], which is typically recited every morning in most schools today (Zinn \& Stefoff, 2009). The author, Francis Bellamy, was advised not to include the term "equality" in the lyrics of the pledge as a mode to exclude women. Although this seems like rudimentary 
history, many contend that the Pledge of Allegiance is a fundamental experience in U.S. schools that, at its core, is exclusionary towards women.

Aside from these historical implications, gender disparities are learned and reinforced in educational institutions even today (Smyk, 2017). For example, Smyk (2017) found girls are taught to believe that boys are better in math and science. Additionally, the Institute of Physics (2013) also found that most girls avoid S.T.E.M. fields. Thus, the hidden curriculum in many schools, along with reinforced parent stereotypes at home, reinforce gender inferiorities (Smyk, 2017). Shohat and Stam (1994) contend that these gendered categories are by-products of colonial programming and idealized programmings of the West. Here, "science and technology, for example, are often seen as 'Western"' (Shohat \& Stan, 1994, p. 14). This ignores the interdependence of diverse worlds, such as Africa, Asia, Latin America, and indigenous knowledge that foregrounded Western "discoveries" in science and technology.

As a quintessential example, American suffragist Alice Paul expressed how she did not know about political science and economic classes before she attended college (Conversations with Alice Paul, 2015). In the 1970s, Paul later mentions that most women majored in English or Latin, and men majored in economics and political science. These historical disparities help to explain why $85 \%$ of education, English, and liberal arts degrees are awarded to women undergraduates majors, in comparison to engineering and computer science degrees, which are comprised of $83.2 \%$ and $82.4 \%$ men, respectively (Goudreau, 2010). Notwithstanding, White women were often allowed to progress much further than their Black women contemporaries. To that end, the racial implications of colonialism are discussed in the next section.

\section{Colonialism and Race in the U.S.}

[Undergraduate Student]: The first elementary school I attended, a girl made fun of me at recess saying, "you aren't even Black, your mom is White and she has jungle fever." I did not see my mother as Black or White, I saw her as my mother, nor did I understand what jungle fever was but I knew it was an insult because others langhed at me. On the way back inside, I pushed her into a muddy puddle, very silently but aggressively, and hid for the rest of the day after that. Since then I began to question my identity: what is Black, what is White, and who am I?

[University Professor]: I was the only Black girl in most of my classes. I also remember those unforgettable " $n$-word" moments in school. Not people actually calling me an n-word, per se, but literature teachers cavalierly using the word when teaching about Jim Crow or segregation. These moments were distinct, because as an African American child I was always taught never to use that word. There was one particular time when I was the only Black child in my literature class and the teacher asked me my opinions about the word. I was in $4^{\text {th }}$ grade!

Our experiences with racial awareness in school are categorized by feelings of identity negotiation and isolation. It is important to mention that in relation to other social stratification mechanisms, we were aware of race and racial differences at a much younger age - elementary school. Within U.S. contexts, race is most notably associated with transatlantic slavery and the palpable divide between White and Black Americans. The evidence of racial trauma has led researchers like DeGury (2017) to posit the notion of Post-Traumatic Slave Syndrome [PTSS]. DeGury's (2017) research asserts that U.S. slavery has an observable and traumatic effect on the human body and likewise has had perpetual effects in the African American community. Here, PTSS describes the etiology of the adaptive survival behaviors in African American communities that are conduits of colonialism and slavery.

According to Degrury, PTSS is generally produced in two ways. First, multigenerational trauma is often coupled with continued oppression. Second, the absence of opportunity to heal or access the benefits available in the society is another compounding factor. Both of these conditions generally lead to Post Traumatic Slave Syndrome. To that end, there are several signs of PTSS in the human body, including but not limited to: feelings of hopelessness, depression, a general self-destructive outlook, extreme feelings of suspicion towards the perceived negative motivations of others, and violence against self or others. Noteworthy symptoms of PTSS include learned helplessness, literacy deprivation, distorted self-concept, and aversion to the following: members of one's own identified cultural/ethnic group; the mores and customs associated one's own identified cultural/ethnic heritage; and the physical characteristics of one's own identified cultural/ethnic group (Degruy, 2017). However, PTSS is not without critique. Kendi (2016) asserts that the effects of slavery do not necessarily undermine the mental or physical condition of Blacks today; rather, slavery helps to embolden our resiliency and quest for freedom. In this regard, slavery has made opportunities presented to Blacks, not Black behavior, inferior (Kendi, 2016). Notwithstanding, Degruy (2017) and Kendi (2016) agree there is an undeniable relationship between the bigotry of slavery and racist policies today.

Breathe, Baby, Breathe: Clearing the Way for the Emotional Emancipation of Black People documents the visceral responses to the frequent police killings of unarmed Black people and other injustices deriving from racism. The authors contend that African American protesters march, petition, and legislate, but until they confront and diligently work to overcome the lie of Black inferiority, they will not change society or the systems within (Grills, Aird, \& Rowe, 2016). Grills, Aird, and Rowe (2016) recommend that in order to promote racial justice, the Black 
community must address the root cause of racial injustice and the psychological impact on people within and outside of the Black community. Furthermore, they argue that the fallacy of Black inferiority often motivates biases against African Americans. This leads to discrimination in almost every facet of life, including but not limited to: criminal justice, housing access, job placements, healthcare, and even self-determination. The self-actualization process of being Black, often referred to as nigresscence, comes with preexisting negative connotations (Cross, 1971, 1991).

\section{DECOLONIAL EDUCATION AS A FORCE OF ACTIVISM}

[Undergraduate Student]: In elementary school, we had an assembly where presenters would come in with a huge Banana Snake and the teachers told us all to yell "I'm Black and I'm proud." Every time we had that assembly, all of us would be excited to experience those two things but at the time it did not occur to most why that was so important. For me however, I knew it gave me a sense of belonging and self-love.

[University Professor]: I distinctly remember being on a Transformative Black Education course where I was exposed to precolonial history and it changed my life. It was the first time that I studied about Black achievements in contradistinction to colonization. I felt so much pride knowing about Black bistory unrelated to Whiteness, colonialism, and slavery.

Our own decolonial self-actualizations were created through moments of empowerment and pride. It is evident in both of our narrative snapshots that these were also moments of transformation. To that end, education and schooling have the power to transform citizenry (Freire, 1970/2000). Critical education is generated by a collective effort as a site of resistance. This notwithstanding, hooks (1994) asserts that this is only possible when teachers and students seek self-actualization by way of delving into our personal histories and introspective identities (Sarma, 2019). This is especially true for decolonial educational frameworks found in history and social science disciplines. History and social science [sociology, gender studies, criminal justice, anthropology, political science, geography, psychology, etc.] address controversial issues in society, from "climate change and migration, to access to education and healthcare, to big data, and much more" (Campaign for Social Sciences, 2016, p. 4). Yet, whereas these critical subjects foster critical thinking and solicit a variety of perspectives (Olsen, 2005), the K-16 educational system typically places more value mathematics and science classes. This is due, in part, to the marketization and standardization of U.S. curricula. Additionally, this can also be confirmed via pay disparities among university faculty (Jaschik, 2016), high-stakes assessments in K-12 $1{ }^{6}$ schools (Kennedy \& Clark, 2015), and the $21^{\text {st }}$ century focus on S.T.E.M. sciences and careers (ibid.).

While we advocate for decolonial education as a mode of praxis and self-actualization, many K-12 school districts avoid controversial issues and subjects. For example, the 2014 shooting death of Michael "Mike" Brown in Ferguson, Missouri serves as an exigent example when local schools banned classroom conversations about racial injustice, police brutality, and the Black Lives Matter protestors (Crouch, 2014). More recently, in 2018, a Wisconsin school district banned classroom conversations on "White privilege" (Johnson, 2018). These conversations are likely avoided due to illogical theories of colorblindness - meaning the avoidance of racial difference, administrative pressures, and today's widespread political division. This avoidance of debate serves to protect White fragility and ignores the needs of students of color. With the most recent 2020 uprising in over the deaths of Walter Wallace, Jr. (Chavez, 2020), George Floyd (Murphy, 2020), Ahmaud Arbery (McLaughlin, 2020), Breonna Taylor (Costello \& Duvall, 2020), and Tony McDade (Deliso, 2020), these global protests showcase a tremendous need for critical conversations in classroom spaces. Thus, this article has relevance for U.S. schools as the wounds of the country's racialized past are re-emerging. As we just recently ushered in the $400^{\text {th }}$ year since U.S. slavery in Virginia in 1619, there is much to explore in the context of decolonial education frameworks (Wiggan, 2018). Considering that the perils of American slavery and racism are still evident in the U.S. over 400 years later, the relevance of this article is especially timely considering the recent resurgence in the media's reporting of racial injustice in the U.S.

We maintain that critical approaches in education need to address historical inaccuracies and assimilationist narratives in curricula. Irrefutably, educational discourse in the U.S. propagates inaccurate histories (Loewen, 1995; Nieto \& Bode, 2008). European hegemony found in textbooks often limits access to multicultural perspectives (Gramsci, 1999; Dei, 2003, 2012; Nieto \& Bode, 2008). To that end, many of today's students fail to make important historical connections (PennLive Editorial Board, 2011). For example, according to the National Assessment of Education Progress [NAEP], only 18\% of U.S. eighth graders are proficient in history (Nation's Report Card, 2014). One of the most startling results from a 2011 poll revealed that only $2 \%$ of U.S. twelfth graders could identify the social issue surrounding the 1954 Brown v. Board of Education decision, which was the landmark U.S. Supreme Court decision that banned racially segregated schooling (PennLive Editorial Board, 2011). Historical incompetence is a foundational limitation when discussing contemporary issues.

${ }^{6} \mathrm{~K}-12$ describes kindergarten through high school education [typically ages 5-18 years old].

$8 / 16$

(C) 2020 by Author/s 
Across U.S. schools, African American contributions are often limited to slavery and the Civil Rights Movement. While these are notable moments in U.S. history, this widely ignores triumphant moments in Black history, such as pre-colonial African history, the Harlem Renaissance, Rosewood, Tulsa's Black Wall Street of the 1920 s, etc. The thwarted misconceptions regarding the contributors and maligners of history have unequivocally shaped systems of power in the U.S. Unfortunately, this has been heightened by the standardization and marketization of curricula in the $20^{\text {th }}$ and $21^{\text {st }}$ centuries. According to Listyna, Lavadenz, and Nelson (2004):

As a direct consequence of this political climate, public schools are being inundated with pre-packaged and teacher-proof curricula, standardized tests, and accountability schemes... many of them have been proven in the past to be unsuccessful. (p. 5)

Considering that today's academic climate is situated within a "post-truth era" (American Educational Research Association, 2019), education is important in disentangling cultural and oppositional truths from engrained social, religious, and political ideologies. Much of the curricula is sentimentalized and ignores the inextricable impacts of race and bigotry in American history (Zinn \& Stefoff, 2009).

Research shows that children form diverse opinions about the world starting in early childhood (Zeece, 1997). It is also consistently confirmed in research that teaching multiculturalism can provide many benefits for children, including both students of color and White students (Martin, 2013). To that end, Chapman-Hilliard and AdamsBass (2016) suggest that providing people of color with a historical and comprehensive view of history can aid in psychological liberation and facilitate mental health. And whereas statues and monuments are being pulled down around the world amidst the recent Black Lives Matter protests of 2020 (Ebrahimji \& Moshtaghian, 2020), there is still much work to do in relation to disentangling systems of power in classroom pedagogy.

According to UNESCO, education should be a means to empower children and adults alike to become active participants in the transformation of their societies (Role of Education, 2017). Foshay (1991) similarly notes, "the one continuing purpose of education, since ancient times, has been to bring people to as full a realization as possible of what it is to be a human being" (p. 227). Moreover, critical theorists such as Dei $(2003,2012)$ and Freire $(1970 / 2000,1973)$ have also highlighted the humanistic power of critical pedagogy in transforming citizenry. As such, in the discussion that follows, we disentangle two concepts that inform decolonial educational frameworks: critical thinking and praxis, and education as a tool of empowerment and force of change.

\section{DISCUSSION}

We engage in research that explores educational equity and inequity from a critical lens. As two Women of African Descent in different roles in the academy, this autoethnography explores our own intersectional identities in relation to retrospective educational experiences (Crenshaw, 1991). By doing so, we utilize collaborative critical autoethnography as a form of resistance by recasting our own K-16 educational experiences. More specifically, we highlight our epistemological pathways of knowing and understanding through the lens of decoloniality. To embrace decolonial learning, education should be marked by self-directed learning and egalitarian democratic participation in a pedagogical environment. One precursor to this is the importance of critical thinking and praxis, which are discussed in the following subsection.

\section{Critical Thinking and Praxis}

[Undergraduate Student]: Taking social science courses, I have been learning and unpacking the origins of U.S history, its laws and economy and how it translates to issues we see today. Most of the people I meet in college are outraged about current issues we see today but cannot gather those thoughts and ideas and put them into action to make change.

[University Professor]: I learned about Native Americans in elementary school. I grew up in the Great Plains Midwest, so we always did a specified unit on the LaCroix and Sioux Native American tribes. But we still learned about Christopher Columbus! It was not until I read "Lies My Teacher Told Me" that I had any concept of educational propaganda. This was a required reading in an undergraduate education course, and we had to critically think about the falsification of history. It was then that I realized that my $K-12$ social studies experience had, in a way, failed me. I realized that my elementary experience provided a failed attempt at multiculturalism. Even with Native American acknowledgment, they still tanght us the lie!

We find decolonial education inextricably helpful in our self-actualization process of race, gender, and identity. Through history and social sciences classes, like Women and Gender Studies, Africana Studies, psychology, sociology, etc., we better understand the role of U.S. colonialism in social stratification. Thus, we are able to selfactualize and reimagine our experiences through decolonial lenses. We attribute this to the one essential component of decolonial education: critical thinking/inquiry. Teaching and learning in traditional school contexts is often repressive of critical pedagogy and inquiry (Freire, 1970/2000; hooks, 1994). This has been compounded with the recent marketization of education via standardized assessments. Considering that critical dialogue is the bedrock 
for educational praxis, there is a need to examine the relationship between identity and self-actualization for students of color. The insidious ways that education continues to reify gender and racial disparities requires critical thinking and inquiry from both students and teachers. This proves especially important for African American students since many teachers implicitly project deficit ideologies (Irvine, 1990). Yet, Mignolo and Walsh (2018) attribute critical reflecting and analyzing as ongoing and essential practices for decoloniality. While we acknowledge that critical thinking is present in other disciplines, the intersection of history, social science, and identify formation is paramount.

Giroux (1997) critiques the "death of history" phenomenon and suggests that many educational scholars fail to believe historical concepts are insightful for the future. As noted in our autoethnographic narratives above, we observed the tangible relevance of decolonial education in our lives today. Memories from childhood and early education shaped our present understandings of race and identity. As such, Giroux (1997) further asserts, "to ignore history represents an assault on thinking itself" (p. 5). Since education undoubtedly shapes our ideas about race, class, gender and systems of inequality and privilege (Wiggan, 2011), there is much to be discussed in relation to education's role in shaping citizenry.

Critical thinking is especially important in the current educational climate that celebrates rote memorization, standardization, and rudimentary learning (Smith \& Szymanski, 2013). In that same vein, many researchers today fear that critical thinking is a dissipating skill (Willingham, 2007). Katz (2014) describes the toxic culture of education and asserts that the educational system is so focused on grades and rudimentary testing, that students are afraid to learn. In relation to critical thinking, hooks' (2010) Teaching Critical Tbinking notes:

Sadly, children's passion for thinking often ends when they encounter a world that seeks to educate them for conformity and obedience only. Most children are taught early on that thinking is dangerous. (p. 8)

In Katz' (2014) estimation, since the passage of high-stakes standardized assessments, such as No Child Left Behind, Common Cores State Standards, and Race to the Top federal initiatives, we have perpetuated a false sense of failure in our schools.

Critical thinking is a process that requires analysis and reflection in order to reach conclusions. Only through analysis and self-reflection are we able to analyze the imperative needs of our communities and ourselves. In this sense, critical thinking is less concerned with correctness, rather the process. According to the Foundation for Critical Thinking (2017) there are six developmental stages of becoming a critical thinker, including the unreflective, challenged, beginning, practicing, advanced, and master stages. Considering the developmental stages of critical thinking, it is apparent that it requires diligence and practice. Thus, it is important for teachers to embed critical thinking into classroom curricula. In this sense, Freire (1970/2000) posits the value of critical pedagogy and critical dialogue. According to Freire's (1973) Education for Critical Consciousness and Pedagogy of the Oppressed (1970/2000), transformative social change is only possible through dialogue, critical thinking, and critical questioning. Whereas many contemporary societies favor "mutism" or the silence of oppressed groups as a form of social control, critical dialogue and questioning solicits social change. Giroux (1997) likewise supports Freire's (1970/2000) theories of dialogue and stresses the importance of relationship building through critical thinking and democratized education. Yet, today's educational system inaccurately elevates positivism and places minimal value on student perspectives and meaning-making (Giroux, 1997). Although this study is exploratory and introspective in nature, many of our autoethnographic accounts of educational praxis required an acute self-awareness that hinged on critical thinking and inquiry. As such, educational praxis is discussed in more detail in the next subsection.

\section{Education as a Tool of Empowerment and Force of Change}

[Undergraduate Student]: Many of my friends have not been through the stage of burt, anger and confusion until college because of the lack of information given to them in grade school. Because I had that opportunity early on, coupled with what I am learning in college today, I am able to effectively make change in my community. If more elementary, middle and high schools across our nation created or provided a space for critical thinking and exploring, there would be much more progress.

[University Professor]: I first learned in-depth about Afrocentricity in college. I read Molefi Asante's work and being so intrigued by the concept of Blackness, power, and self-liberation. I later took an Education as a Self-Healing Power class in graduate school and became a scholar in Afrocentric theory and education. Within the Black community, however, Afrocentricity is a politicized word. I quickly realized that not everyone who was Black was Afrocentric. I expected White people not to embrace it, but I was not prepared for Black people to distance themselves from the term. This was also one of my first self-actualizations of internalized hatred. I was (and still am) baffled sometimes at people's disdain for the term "Afrocentricity," because this term bas brought tremendous bealing to my life.

We found hope and healing in acknowledging racial pride and invoking self-love. In both of our narratives, we found sources of healing in transformative educational courses. Yet, for many people dedicated to decolonial and critical framing, the reach of these courses needs to be extended. Freire asserts that this is not coincidence, but rather a quintessential byproduct of education's initial design. 
Freire's (2016) Pedagogy in Process contends:

The culture of the colonized was a reflection of their barbaric way of seeing the world. Culture belonged only to the colonizers. The alienating experience of colonial education was only counteracted for the colonized at those moments when, in an urge for independence, they rejected some of its aspects. (p. 8)

Similarly, hooks' (2010) Teaching Critical Thinking asserts:

Since there has not been a radical transformation of education at its roots, education as the practice of freedom is still a pedagogy accepted only by individuals who elect to concentrate their efforts in this direction. (p. 27)

This means, as our narratives suggest, that transformative and emancipatory education is often the byproduct of those from oppressed groups who seek alternative ways of knowing. As such, this information is not typically accessible to all students.

While we agree with hooks' (1994), Freire's (1970/2000, 1973), and Giroux's (1997) propositions about critical education and praxis, this autoethnography centers identity and diversity within the learning experience. Since the $21^{\text {st }}$ century has ushered a new milieu for politicized racial oppression, the need for decolonial educational framing is paramount. Interestingly, whereas the framework for this article is centered in decolonial intersectionality, many of our experiences compartmentalized race and gender separately. This supports Grzanka's (2014) notions that intersectionality for Black women is not simply a theory about identity, but rather:

... a structural analysis and critique insomuch as it is primarily concerned with how social inequalities are formed and maintained; accordingly, identities and the policies thereof are the products of historically entrenched, institutional systems of domination and violence (p. 10).

In relation to education, researchers Ighodaro and Wiggan (2011) coin the term "curriculum violence" to describe the pervasive psychological damages caused by cultural misinformation and Eurocentric standardization. The duplicitous nature of standardized curricula falsely propagates educational equity without sufficiently interrogating the extent of curricular variance and diversity. As two Women of African Descent, we provided experiences of U.S. educational mismanagement across K-16 schooling along with modes of resistance. Inasmuch, our collective autoethnography provides diverse depictions within decolonial intersectionality, as both student and teacher.

Our narratives also provide evidences of renewed hope and healing from decolonial education, which we believe could spur widespread and systemic change. Ginwright (2016) explains that hope is an important form of political and social resistance, while healing alleviates damages from systemic and structural oppression. Within urban communities of color, teachers, activists and community leaders should use both bope and healing as approaches to counteract student trauma. In relation to education, the dilution and omission of important racial narratives, also known as curriculum violence, has negatively influenced both teachers and students.

Beckett (2014), DeGury (2017), Smith and Patton (2016), and Tokuda (2014) contend that the impact of Black criminalization has long-term effects on psychological and physiological health. Researchers find that present-day violence, poverty, and police-inflicted trauma impact mental and physical health (Tokuda, 2014). These compounding issues have inextricable consequences for education and learning outcomes. Yet, effective solutions have often failed to meet the needs of a nation tarnished by racial distortions and bigotry. Policy makers generally tend to focus on individual communities and failing schools, while ignoring the surrounding environments that create trauma and stress. In that same vein, social justice organizers often focus outwardly on temporary fixes in the community, without acknowledging mental health, anxiety, and depression that thwart communities of color. We believe education plays an integral role in mediating collective healing. Ginwright (2016) proposes using a collective hope approach, which includes transformative organizing, restorative justice, healing circles, and mindfulness practices. Here, schools play a vital role in facilitating critical conversations that empower and venerate students of color. Whereas state and national curricula are often standardized, we agree with Freire (2016) and hooks (1994) on the role of dialectic teacher-student and student-student interactions that disrupt bigotry and oppression.

Additionally, there is an abundance of existing research on mindfulness and restorative justice in schools (Zenner, Herrnleben-Kurz, \& Walach, 2014). Researchers are now beginning to investigate the usefulness of mindfulness with helping communities of color process internal trauma (Seaman, 2015). There needs to be a more concentrated focus on policies that create and sustain productive living and learning conditions, as well as the psychological and spiritual mechanisms of positive meditation and mindfulness. Giroux's (1997), Freire's (1973, 2016), and hooks' (1994) research supports these notions. When reflecting on our own autoethnographic narratives, we retrospectively ponder the endless possibilities for healing if our schooling experiences had facilitated these important decolonial conversations much earlier. While we had parents who provided initial guidance and 
college classes that further expanded our worldviews on race, gender, and intersectionality, we believe these opportunities are important for younger students as well.

\section{CONCLUSION}

In Teaching to Transgress, hooks (1994) emphatically asserts that the educational is inextricable from the personal (Sarma, 2019). Our collaborative critical autoethnography highlights the importance of this assertion. In our reflections on past schooling experiences, our collective understandings of race were inseparable from personal moments of "self-actualization" (p. 24). Yet, while hooks (1994) shares insights and critical reflections as an intervention to "counter the devaluation of teaching" (p. 10), we suggest that the U.S. teaching field has maintained enormous power through the ways in which knowledge is subversively controlled in schools. This is most evident in the avoidance of critical discussions and the omission of non-dominant perspectives from curricula (Johnson, 2018; Loewen, 1995). hooks further suggests that transformative education is made possible through expanded and engaged pedagogy; however we suggest that curricula are central to this discussion as well. Thus, in an effort to combat both the standardization of U.S. curricula and sterilization of research discourse, this autoethnography offers evidence for the transformative power of decolonial education through the lens of lived participants.

The above collaborative critical autoethnography provides reflections from an undergraduate student and university professor, both of whom are Women of African Descent. Our use of autoethnography contributes to existing debates on race, education, and social justice by introspectively exploring how institutional racism manifests in personal educational experiences. In this regard, we suggest the requirements for transformative education should expand beyond classroom pedagogy, as hooks (1994) suggests, to also include state and national curricula. In fact, our collaborative critical autoethnography expressively highlights that course material, not necessarily teaching style, has been most transformative in our own educational experiences. This is an important observation to note. We hope this discussion will expand future discourse on transformative education to also include an interrogation of course material and curriculum content.

Our narratives ponder past K-16 schooling experiences and education's role in being a divider or equalizer in American society. These rich cultural considerations help to inform existing research on decolonial frameworks and educational praxis while offering an expanded milieu for racial awareness in the $21^{\text {st }}$ century U.S. Using decoloniality as our lens, we establish that American society has impelled race and gender disparities in many ways, including education. Considering that education is one of the major institutions that shape American lives, it is important to reconsider effective classes that help students better understand their social conditions. From our experiences, decolonial education has helped us to better understand social inequality and oppression. When taught critically, education fosters critical thinking/inquiry and allows students to begin personal praxis (Olsen, 2006; Freire, 1973). It is important for students to understand the longstanding history of colonial stratification, including but not limited to: slavery, slave codes, vagrancy laws, lynching, Jim Crow laws, restrictive housing, eugenics, mass incarceration, gentrification, the War on Drugs, and police brutality, in order to recognize its compounding effects today. With today's resurgence of racism and political bigotry, decolonial education and empowerment prove increasingly paramount for African American students.

hooks (1994) argues that the classroom, "with all its limitations, remains a location of possibility" (p. 207). As such, our collaborative critical autoethnography suggests that educational settings provide enormous opportunities to explore institutional systems rooted in race and racism. Yet, these critical opportunities are strategically made less visible through the standardization of school curricula. Whereas many critical courses [such as Women's and Gender Studies, Africana Studies, etc.] are typically not introduced until college, the topics of culture, gender, race, politics, psychology, sociology, criminal justice, etc. are important for all students, even at the K-12 level. Considering that education has the power to transform citizenry, this is an important area to explore.

\section{REFERENCES}

Adams, T. E., Jones, S. H., \& Ellis, C. (2014). Autoethnography. Oxford, UK: Oxford University Press. Alexander, M. (2012). The new Jim Crow: Mass incarceration in the age of color blindness. New York, NY: The New Press. American Educational Research Association. (2019). 2019 Annual Meeting Theme. Leveraging education research in a "post-truth" era: Multimodal narratives to democratize evidence. American Educational Research Association. Retrieved from https://www.aera.net/Events-Meetings/Annual-Meeting/2019-Annual-Meeting-Theme

Anderson, T. D., \& Fourie, I. (2015). Collaborative autoethnography as a way of seeing the experience of care giving as an information practice. In Proceedings of ISIC, the Information Behaviour Conference, Leeds, 2-5 September, 2014: Part 2, (paper isic33). 
Aristotle. (350 B.C.E./1966). Metaphysics, Vol 1. (W.D. Ross, Trans.). Oxford: Oxford Clarendon Press. (Original work published in 350 B.C.E.).

Asante, M. K. (1990). Kemet, afrocentricity, and knowledge. Trenton, NJ: Africa World Press.

Axtell, J. (1992). Beyond 1492: Encounters in colonial North America. New York, NY: Oxford University Press.

Baker, T. (2020, February 13). The power of teachers to transform. Useable Knowledge: Relevant Research for Today's Educators. Harvard Graduate School of Education. Retrieved from https://www.gse.harvard.edu/news/uk/ 20/02/power-teachers-transform

Barton, P. A. (2001). A bistory of the African-Olmecs: Black civilization of America from prebistoric times to the present era. Bloomington, IN: AuthorHouse.

Beckett, L. (2014). The PTSD crisis that's being ignored: Americans wounded in their own neighborhoods. ProPublica. Retrieved from https://www.propublica.org/article/the-ptsdcrisis-thats-being-ignored-americanswounded-in-their-own-neighbor

Bhattacharya, H. (2008). New critical collaborative ethnography. In S. N., Hesse-Biber \& P. Leavy (Eds.), Handbook of emergent methods (pp. 303-324). New York, NY: Guilford.

Borders, E. (2010). Apart type screenplay. Xlibris Corporation.

Boserup, E. (1970). Woman's role in economic development. London, UK: George Allen and Unwin Ltd.,

Boylorn, R. M., \& Orbe, M. P. (2014). Critical autoethnography: Intersecting cultural identities in everyday life. Walnut Creek, CA: Left Coast Press.

Campaign for Social Sciences. (2016). Annual Report 2015-2016. Retrieved from http:/ / campaignforsocialscience .org.uk/wp-content/uploads/2016/08/CfSS-2015-16-Annual-Report-vFinal-web.pdf

Chang, H. (2008). Autoethnography as method. New York, NY: Routledge.

Chang, H., Ngunjiri, F., \& Hernandez, K.C. (2013). Collaborative autoethnography. Walnut, CA: Left Coast Press.

Chapman-Hilliard, C., \& Adams-Bass, V. (2016). A conceptual framework for utilizing black history knowledge as a path to psychological liberation for black youth. Journal of Black Psychology, 42(6), 479-507. https://doi.org/10.1177/0095798415597840

Chavez, N. (2020, November 1). Unrest after Walter Wallace Jr. shooting boiled over from the disconnect between a Philadelphia community and police. CNN. Retrieved from https://www.cnn.com/2020/11/01/us/ philadelphia-police-community-tensions-walter-wallace/index.html

Chengu, G. (2014, October 14). Before Columbus: How Africans brought civilization to America. Global Research: Centre for Research on Globalization. Retrieved from https://www.globalresearch.ca/before-columbus-howafricans-brought-civilization-to-america/5407584.

Conversations with Alice Paul. (2015). Alice Paul Institute. Retrieved from http://www.alicepaul.org/audiointerview/

Crenshaw, K. W. (1991). Mapping the margins: Intersectionality, identity politics, and violence against women of color. Stanford Law Review, 43, 1241-1299. https:/ / doi.org/10.2307/1229039

Cross, W. E. (1971). The negro-to-black conversion experience. Black World, 20(9), 13-27.

Cross, W. E. (1991). Shades of black: Diversity in African-American identity. Philadelphia, PA: Temple University Press.

Crouch, E. (2014, August 20). Edwardsville teachers told to avoid discussing Ferguson events with students. St Louis Post. Retrieved from http://www.stltoday.com/news/local/education/edwardsville-teachers-told-toavoid-discussing-ferguson-events-with-students/article_1358925d-3e54-5823-9ce3-2f9938fc4c22.html

d'Anghera, P. M. (1912). De orbo novo: The eight decades of Peter Martyr D'Anghera (F. A. MacNutt, Trans.). Gutenberg Project. Retrieved from http://www.gutenberg.org/files/12425/12425-h/12425-h.htm

Dei, G. J. (2003). Communication across the tracks: Challenges for anti-racist educators in Ontario today. Orbit, $33(3), 2-5$.

Dei, G. J. S. (2012). Teaching Africa: Towards a transgressive pedagogy. Dordrecht: Springer.

Deliso, M. (2020, June 2). LGBTQ community calls for justice after Tony McDade, a black trans man, shot and killed by police. $A B C$ News. Retrieved from https:/ / abcnews.go.com/US/lgbtq-community-calls-justice-blacktrans-man-shot/story?id= 71022981

Diop, C.A. (1987). Precolonial black. Africa: A comparative study of the political and social systems of Europe and black. Africa, from antiquity to the formation of modern states. Brooklyn, NY: Lawrence Hill Books.

DuBois, W. E. B. (1899). The Philadelphia negro: A social study. Philadelphia, PA: University of Pennsylvania Press.

Defining Critical Thinking. (2015). The Foundation for Critical Thinking. Retrieved from http://www.criticalthinking.org/pages/defining-critical-thinking/766

Coates, T. (2015, July/August). There is no post-racial America. The Atlantic. Retrieved from https://www.theatlantic.com/magazine/archive/2015/07/post-racial-society-distant-dream/395255/

Collins. P. H. (2000). Black feminist thought: Knowledge, consciousness, and the politics of empowerment. Routledge.

Collins, P. H. (2019). Intersetionality: As critical social theory. Durham, NC: Duke University Press. 
Costello, D., \& Duvall, T. (2020, May 15). Minute by minute: What happened the night police fatally shot Breonna Taylor. USA Today. Retrieved from https://www.usatoday.com/story/news/nation/2020/05/15/minuteminute-account-breonna-taylor-fatal-shooting-louisville-police/5196867002/

Critical Thinking in Everyday Life. (2017). The Foundation for Critical Thinking. Retrieved from http:/ / www.criticalthinking.org/pages/critical-thinking-in-everyday-life-9-strategies /512

DeGury, J. (2017). Post traumatic slave syndrome: America's legacy of enduring injury and healing. Portland, OR: Joy Degruy Publications Inc.

Ebrahimji, A., \& Moshtaghian, A. (2020, June 9). Confederate statues are coming down following George Floyd's death. Here's what we know. CNN. Retrieved from https://www.cnn.com/2020/06/09/us/confederatestatues-removed-george-floyd-trnd/index.html

Ferguson, R. A. (2012). Reading intersectionality. Trans-Scripts, 2, 91-99.

Flaherty, J. (2014, May 13). New Orleans teachers and students wrestle with racial tension. The Root. Retrieved from http://www.theroot.com/articles/culture/2014/05/new_orleans_schools_plagued_by_racial_tension/

Foshay, A. (1991). The curriculum matrix: Transcendence and mathematics. Journal of Curriculum and Supervision, 6(4), 277-293.

Foster, D. (2015, July). Women's paid and unpaid work, and the colonial hangover. Open Democracy 50/50. Retriefed from https://www.opendemocracy.net/5050/dawn-foster/women's-paid-and-unpaid-work-and-colonialhangover

Freire, P. (1970/2000). Pedagogy of the oppressed. New York, NY: Continuum International Publishing Group.

Freire, P. (1973). Education for critical consciousness. New York, NY: Continuum International Publishing.

Freire, P. (2016). Pedagogy in process: The letters to Guinea-Bissau. New York, NY: Bloomsbury Publishing. https://doi.org/10.5040/9781474268950

George, J. \& Puente, M. (2015, March 14). Baltimore leaders agree: City has a race problem. The Baltimore Sun. Retrieved from http://www.baltimoresun.com/news/maryland/baltimore-city/bs-md-ci-baltimore-racism20150314-story.html

Ginwright, S. A. (2016). Hope and healing in urban education: How urban activists and teachers are reclaiming matters of the beart. New York, NY: Routledge. https:// doi.org/10.4324/9781315757025

Giroux, H. A. (1997). Pedagogy and the politics of hope. Colorado: Westview Press.

Gleiman, A., Knolton, D., \& Mokhtarian, K. (2015). The art of collaborative autoethnography: Exploring the evolution of a self-organizing, non-traditional doctoral cohort. Open Access Library Journal, 2, 1-11. https://doi.org/10.4236/oalib.1101634

Goodwin, B. (2014). Research says / teach critical thinking to teach writing. Educational Leadership, 71(7), 78-80.

Gordreau, J. (2010, August 10). Most popular college majors for women. Forbes. Retrieved from https:/ /www.forbes.com/2010/08/10/most-popular-college-degrees-for-women-forbes-woman-leadershipeducation-business.html\#67a664c932a1

Gramsci, A. (1999). Selections from the prison notebooks. London, UK: The Electric Book Company Ltd.

Grills, C. N., Aird, E. G., \& Rowe, D. (2016). Breathe, baby, breathe: Clearing the way for the emotional emancipation of Black people. Cultural Studies Critical Methodologies, 16(3), 333-343. https://doi.org/10.1177/1532708616634839

Grzanka, P. R. (2014). Intersectionality: A foundations and frontiers. New York, NY: Routledge.

Herodotus. (440 B.C.E./2014). The history of Herodotus, volume 1. (G.C. Macaulay, Trans.). Lexington, KY: CreateSpace Independent Publishing Platform. (Original work published in 440 B.C.E.).

hooks, b. (1994). Teaching to transgress: Education as the practice of freedom. New York, NY: Routledge.

hooks, b. (2010). Teaching critical thinking: Practical wisdom. New York, NY: Routledge.

Institute of Physics. (2013). Closing doors: Exploring gender and subject choices in schools. An Institute of Physics Report. Retrieved from http:/ /www.iop.org/publications/iop/2013/closingdoors /

Irvine, J. J. (1990). Black students and school failure: Policies, practices, and prescriptions. New York, NY: Preager.

Johnson, A. (2018, March 9). Oconomowoc schools impose limits on 'privilege' discussions after parents complain. Milwaukee Journal Sentinel. Retrieved from https://www.jsonline.com/story/news/education/2018/03/09/ oconomowoc-schools-impose-limits-privilege-discussions-after-parents-complain/407222002/

King, J. E., \& Swartz, E. E. (2018). Heritage knowledge in the curriculum: Retrieving an African episteme. New York, NY: Routledge. https://doi.org/10.4324/9781351213233

Kurtiş, T., \& Adams, G. (2017). Decolonial intersectionality: Implications for theory, research, and pedagogy. In K. A. Case (Ed.), Intersectional pedagogy: Complicating identity and social justice (p. 46-59). New York, NY: Routledge. https://doi.org/10.4324/9781315672793-3

Law, R. (1989). Between the sea and the lagoons: The interaction of maritime and inland navigation on the precolonial slave coast. Cahiers d'Études Africaines, 29(114), 209-37. https://doi.org/10.3406/cea.1989.1643 
Leistyna, P., Lavandez, M., \& Nelson, T. (2004). Introduction — Critical pedagogy: Revitalizing and democratizing teacher education. Teacher Education Quarterly, 31(1), 3-15.

Loewen, J. W. (1995). Lies my teacher told me: Everything your American history textbook got wrong. New York, NY: The New Press.

Lorde, A. (1984/2007). Sister outsider: Essays and speeches. Crossing Press.

Kendi, I. X. (2016, June 21). Post-traumatic slave syndrome is a racist idea. Black Perspectives. Retrieved from https:/ /www.aaihs.org/post-traumatic-slave-syndrome-is-a-racist-idea/

Kennedy, T. A., \& Clark, J. (2015, November 20). Students need STEM education for $21^{\text {st }}$ century economy. US News and World Report. Retrieved from https://www.usnews.com/news/stem-index/articles/2015/11/20/oped-students-need-stem-education-for-21st-century-economy

Martin, D. (2014). Good education for all? Student race and identity development in the multicultural classroom. International Journal of Intercultural Relations, 39, 110-23. https:// doi.org/10.1016/j.ijintrel.2013.10.005

Marks, J. (2008). "Race: Past, present and future." In B. Koenig, S. Soo-Jin Lee, \& S. S. Richardson (Eds.). Revisiting race in a genomic age. Rutgers, NJ: Rutgers University Press.

Marx, S., Pennington, J. L., \& Chang, H. (2017). Critical autoethnography in pursuit of educational equity: Introduction to the IJME special issue. International Journal of Multicultural Education, 19(1), 1-6. https://doi.org/10.18251/ijme.v19i1.1393

McLaughlin, E. C. (2020, May 12). What we know about Ahmaud Arbery's killing. CNN. Retrieved from https://www.cnn.com/2020/05/11/us/ahmaud-arbery-mcmichael-what-we-know/index.html

Mignolo, W. (2007). Delinking. Cultural Studies 21(2-3): 449-514. https://doi.org/10.1080/09502380601162647

Mignolo, W. (2011). The darker side of western modernity: Global futures, decolonial options. Durham, NC: Duke University Press. https://doi.org/10.1515/9780822394501

Mignolo, W. D., \& Walsh, C. E. (2018). On decoloniality: Concepts, analytics, praxis. Durham, NC: Duke University Press. https:// doi.org/10.1515/9780822371779

Moore, J., Scarduzio, J.A., Plump, B., \& Geist-Martin, P. (2013). The light and shadow of feminist research mentorship: A collaborative autoethnography of faculty-student research. Journal of Research Practice, 9(2), 1- 24.

Moulthorp, D. (2015, February 19). Cleveland's race problem: How longstanding injustice could cripple the city's rebirth. Politico Magazine. Retrieved from http://www.politico.com/magazine/story/2015/02/clevelandsegregation-115320

Murphy, P. P. (2020, June 3). New video appears to show three police officers kneeling on George Floyd. CNN News. Retrieved from https://www.cnn.com/2020/05/29/us/george-floyd-new-video-officers-kneeltrnd/index.html

Napolitano, A. (2009). Dred Scott's revenge: A legal history of race and freedom in America. Nashville, TN: Thomas Nelson.

Nation's Report Card. (2014). U.S. history assessment. National Assessment of Educational Progress [NAEP]. Retrieved from https://www.nationsreportcard.gov/hgc_2014/\#history/achievement

Nieto, S., \& Bode, P. (2008). Affirming diversity, The Sociopolitical context of multicultural education (5th ed.). Boston: Allyn \& Bacon.

Olsen, J. (2005). Critical thinking in political science: Evidence from the introductory comparative politics course. Journal of Political Science Education, 1(3), 323-344. https: / / doi.org/10.1080/15512160500261186

O’Neil, P. (2015). Essentials of comparative politics (5th ed.). New York, NY: W. W Norton \& Company.

O’Neil, P., \& Rogowski, R. (2013). Essential readings in comparative politics (4th ed.). New York, NY: W.W Norton \& Company.

PennLive Editorial Board. (2011, July 3). Lack of American history knowledge is disturbing. PennLive. Retrieved from http://www.pennlive.com/editorials/index.ssf/2011/07/americans_lack_of_history_know.html

Plutarch. (75 C.E./2012). Parallel lives vol. 1. Radford, VA: SMK Books. (Original work published in 75 C.E.).

Press TV. (2014, March 24). Discrimination in US education system widespread for minorities [Video file]. Retrieved from https://www.youtube.com/watch?v $=15 \mathrm{mZuVeYrIU}$

Role of Education. United Nations Educational, Scientific, and Cultural Organization [UNESSCO]. (2017). UNESCO. Retrieved from http://www.unesco.org/new/en/social-and-human-sciences/themes/fightagainst-discrimination/role-of-education/

Roosevelt, E. (1930). Good citizenship: The purpose of education. Pictorial Review, 4, 94, 97.

Salem, S. (2014, April 17). Decolonial intersectionality and a transnational feminist movement. The Feminist Wire. Retrieved from https://thefeministwire.com/2014/04/decolonial-intersectionality/

Sanders, E. (1969). The Hamitic hypothesis, its origins and functions in time perspective. JAH, 10(4), 521-532. https://doi.org/10.1017/S0021853700009683

Sarma, S. (2019, June 5). Teaching to transgress by bell hooks - a reflective review. Critical Edges. Retrieved from https://criticaledges.com/2019/06/05/teaching-to-transgress/ 
Seaman, A. M. (2015, December 18). School-based mindfulness training may reduce stress, trauma. Reuters Health. Retrieved from https://www.reuters.com/article/us-health-mindfulness-stress-school/school-basedmindfulness-training-may-reduce-stress-trauma-idUSKBNOU12MY20151218

Semali, L. M., \& Kincheloe, J. L. (1999). "Introduction: What is indigenous knowledge and why should we study it.” In L. M. Semali \& J. L. Kincheloe (Eds.) What is indigenous knowledge? Voices from the academy. New York, NY: Routledge.

Shaw, S., \& Lee, J. (2015). Women's voices, feminist visions: Classic and contemporary readings (6th ed.). New York, NY: McGraw Hill.

Shohat, E., \& Stam, R. (1994). Unthinking eurocentrism. New York, NY: Routledge.

Smedley, A. (1999). Race in North America: Origin and evolution of a worldview (2nd ed.). Boulder, CO: Westview Press.

Smith, J. R., \& Patton, D. U. (2016). Posttraumatic stress symptoms in context: Examining trauma responses to violent exposures and homicide death among Black males in urban neighborhoods. Journal of Orthopsychiatry, 86(2), 212-223. https://doi.org/10.1037/ort0000101

Smith, V. G., \& Szymanski, A. (2013). Critical thinking: more than test scores. NCPEA International Journal of Educational Leadership Preparation, 8(2), 16-26.

Smyk, M. (2017). Gender beliefs and planned occupation: High school pupils and their parents. Group for Research in Applied Economics, 3, 1-13.

TEDx Talks. (2014, May 2). Toxic culture of education: Joshua Katz at TEDx University of Akron [Video file]. Retrieved from https://www.youtube.com/watch?v=BnC6IABJXOI

“The Importance of Critical Thinking." (2016). Argument: It's Always Good to See Both Sides. Retrieved from https:/ /www.bothsidesoftheargument.ca/the-importance-of-critical-thinking/

Thurber, A., Harbin, M. B., \& Bandy, J. (2020. Teaching race: Pedagogy and practice. Vanderbilt University Center for Teaching. Retrieved from https://cft.vanderbilt.edu/guides-sub-pages/teaching-race/

Tokuda, W. (2014, May 16). "Inner -city Oakland youth suffering From PTSD." CBS News.Retrieved from http://sanfrancisco.cbslocal.com/2014/05/16/hood-disease-inner-cityoakland-youth-suffering-from-posttraumatic-stress-disorder-ptsd-crime-violenceshooting-homicide-murder/

Van Sertima, I. (1976/2003). They came before Columbus: The African presence in ancient America. New York, NY: Random House.

Whitewright, J. (2018). The ships and shipping of Indo-Roman trade: A view from the Egyptian red sea. HEROM. Journal on Hellenistic and Roman Material Culture, 6(2), 137-171. https:/ / doi.org/10.11116/HEROM.6.2.1

Wiener, L. (1922). African and the discovery of America. Philadelphia, PA: Innes and Sons.

Wiercinski, A. (1972d). An anthropological study on the origin of "Olmecs." Swiatowit, 33, 143-174.

Wiggan, G. (2011). Power, privilege, and education: Pedagogy, curriculum, and student achievement. Hauppauge, NY: Nova Science Publishers.

Wiggan, G. (2018). Afterword: Black migrations and urban realities. Black History Bulletin, 81(2), 30-33. https://doi.org/10.5323/blachistbull.81.2.0030

Wiggan, G., Scott, L. M., Watson, M. J., \& Reynolds, R. (2014). Unshackled: Education for freedom, student achievement and personal emancipation. Rotterdam, Netherlands: Sense-Springer Publishers. https://doi.org/10.1007/978-946209-524-3

Williams, E. (1994). Capitalism and slavery. Chapel Hill, NC: The University of North Carolina Press.

Willingham, D. T. (2007). Critical thinking: Why is it so hard to teach? American Educator, 31(2), 8-19.

Wolfe, K. A., Nelson, A. B., \& Seamster, C. L. (2018). In good company: A collaborative autoethnography describing the evolution of a successful doctoral cohort. International Journal of Doctoral Studies, 13, 293-311. https://doi.org/10.28945/4078

Zakaria, F. (2007). The future of freedom: Illiberal democracy at home and abroad. New York, NY: W. W. Norton \& Company.

Zenner, C., Herrnleben-Kerz, S., \& Walach, H. (2014, June 30). Mindfulness-based interventions in schools - a systematic review and meta-analysis. Frontiers in Psychology. https://doi.org/10.3389/fpsyg.2014.00603

Zinn, H \& Stefoff, R. (2009). A young people's history of the United States. (Enhanced Omnibus/Paperback ed.). New York, NY: Seven Stories Press. 